\title{
Actual problems of the non-pecuniary damages' assessment by the European Court of Human Rights
}

\author{
V. D. Sherstiuk \\ Taras Shevchenko National University of Kyiv, Ukraine \\ Corresponding author. E-mail: Sherstiukvladyslav@gmail.com \\ Paper received 16.08.21; Accepted for publication 08.09.21.
}

\section{https://doi.org/10.31174/SEND-HS2021-258IX47-06}

\begin{abstract}
The article is devoted to the awarding of non-pecuniary damages in the European Court of Human Rights (ECHR) practice. The problem of research arises from the lack of criteria that the Court uses for calculating non-pecuniary damages which leads to unfair compensation for the injured party. The article examines ECHR cases and investigates how the Court has substantiated the precondition for a claim for compensation of non-pecuniary damage of a person. The grounds and circumstances which influence the amount of non-pecuniary damages are analyzed. The research proposes to define and introduce a list of criteria based on individual features of a person in recommendations on which ECHR should pay attention in non-pecuniary damages assessment to provide fair compensation to the victim which can help to create transparent mechanism for assessment in its practice.
\end{abstract}

Keywords: non-pecuniary damage (NPd), human rights, the European Court of Human Rights (ECHR), criteria for damage assessment, compensation, just satisfaction.

Introduction. At the present stage of development of the world community the problem of human rights and its violation is one of the most actual. Several international legal acts have been adopted, which determine a person the highest value of society, and the proper protection of his rights and freedoms is the main duty of a democratic state.

The modern legal paradigm notices "the rise of nonpecuniary damage in European law" [1]. In the core of the concept of the NPd that are typically things like pain and suffering, loss of quality of life, emotional distress as a result of moral or physical suffering or other negative phenomena caused to the person by the unlawful acts or omissions of others.

It is the securing of the obligation of the human rights and freedoms that guarantees the rights of the person, in case of violation of the latter, to go to court in order to protect and restore them, as well as to compensate for the harm caused by such violation. The formation and development of the institution of compensation for moral harm depends both on the socio-political situation in the country, and on the cultural and spiritual development of society. This process, due to its dynamism, requires constant attention of the legislator and timely improvements, in view of changes in the moral and spiritual values of individuals and society.

The European Convention on Human Rights (ECtHR) empowers the European Court of Human Rights to "allow just satisfaction" for the "injured party", in addition to simply finding and ascertaining human rights violations, Art. 41 [2, Art. 41] rewards, especially those related to moral harm, are often criticized for their inconsistency, subjectivity, lack of reasoning and the resulting unpredictability.

The term "satisfaction" - a form of compensation for damage caused to the injured party as a result of the offense, is most often used in the work of the ECHR in the process of considering cases of compensation for damage committed by the state with internationally wrongful acts. If the Court declares that there has been a violation by the state of the Convention or its Protocols, and the domestic law of the state allows only partial compensation, the Court shall, if necessary, award just satisfaction to the injured party. Art. 41 reads as follows: "If the Court finds that there has been a violation of the Convention or the Protocols thereto, and if the internal law of the High Contracting Party concerned allows only partial reparation to be made, the Court shall, if necessary, afford just satisfaction to the injured party" [2, Art. 41]

The text of Art. 41 itself seems to use "satisfaction" interchangeably with "reparation": by prescribing that the Court may only award "just satisfaction" "if the internal law of the High Contracting Party concerned allows only partial reparation to be made". Also, during the drafting process, the terms "satisfaction", "reparation", and "compensation" have all been employed seemingly without distinction. The Court's Practice Directions use the terms "financial compensation", "monetary award" or "award in respect of pecuniary/non-pecuniary damage" to circumscribe and paraphrase the Convention's term "just satisfaction" [3].

Recent research and publications. Whereas the concept of moral harm and the criteria for its determination were examined in the wide range of theoretical studies [4$6,11,14]$ the question remains unanswered - how does the European Court of Human Rights come to a certain amount of moral harm in each case? What factors play a role in measuring the amount of moral harm when its satisfaction? Despite the active coverage of the ECHR's practice of awarding just satisfaction, there is still a lack of analytical research aimed at identifying the Court's systemic view of the proper structure and basic principles of the functioning of the NPd mechanism. These include assessing the legal nature of this civil liability measure, determining the subjective composition of persons authorized to use it, specific manifestations of probable nonpecuniary losses, establishing appropriate approaches to the exercise of evidence, ensuring legal certainty in matters of awarding appropriate compensation.

The objectives of the research are to analyze criteria 
which ECHR uses in assessment of NPd, systemize them and then find and propose criteria which will help court to provide fair compensation to the victim. Also, to propose grounds and conditions for assessment of NPd based on individual features of a person.

Methodology and research material. The methods which have been used are: 1/ case studying for reviewing the ECHR practice related to the NPd assessment. 2/ Comparative legal analysis method for reviewing how NPd institution was developing in different countries and analyzing criteria which ECHR uses for calculating the amount and awarding of non-pecuniary damages. 3/ Prediction method for analyzing how alternative mechanisms of calculating of NPd will influence the theory and the practice of ECHR.

Discussion. The ECHR, when making a decision on the amount of fair satisfaction, proceeds from the main circumstances of the case, and also has the right to independently establish this satisfaction. Satisfaction is expressed in the fact that the violating state provides satisfaction to the victim. At the same time, satisfaction can be expressed not only in monetary compensation, but also in the form of regret, reassuring the injured party of the inadmissibility of the like, apology, punishment of the guilty, special honors to the affected state, other forms of moral satisfaction of the injured party.

According to the Court, the "guiding principle is equity, which above all involves flexibility and an objective consideration of what is just, fair, and reasonable in all the circumstances of the case, including not only the position of the applicant but the overall context in which the breach occurred [7]. Its non-pecuniary awards serve to give recognition to the fact that moral damage occurred as a result of a breach of a fundamental human right and reflect in the broadest of terms the severity of the damage. According to the Court, the award in respect of NPd "involves flexibility and an objective consideration of what is just, fair and reasonable in all the circumstances of the case" [7].

The Court's Practice Directions put it as follows: "Furthermore, the Court will only award such satisfaction as is considered to be 'just' (équitable in the French text) in the circumstances. Consequently, regard will be head to the particular features of each case. The Court may decide that for some heads of alleged prejudice the finding of violation constitutes in itself sufficient just satisfaction, without there being any call to afford financial compensation. It may also find reasons of equity to award less than the value of the actual damage sustained or the costs and expenses actually incurred, or even not to make any award at all. If the existence of such damage is established, and if the Court considers that a monetary award is necessary, it will make an assessment on an equitable basis, having regard to the standards which emerge from its case-law [8].

How does the Court apply its principle of equity? The main point is the amount claimed by the applicant, which, however, is not binding for the Court. The court does not usually exceed the applicant's claim. Conversely, the Court often disputes the claim. For example, in the case of Konstantin Markin v. Russia, the applicant claimed EUR 400,000 in respect of NPd and the Court awarded EUR 3,000 [9]. In addition, the Court may consider domestic practice in respect of NPd. "Punitive damages" are not part of the just satisfaction award under Art. 41 [2]. ${ }^{1}$ Lastly, the Court's assessment of what is "just" in a particular case is inconclusive, as the Court has repeatedly held.

As noted above, the main consideration of equality is that the amount awarded should reflect "in the broadest possible terms the gravity of the loss" [10]. How does the Court determine the severity of the damage? The case law has two broad components: the seriousness of the infringement applicant- and overall context-related factors.

The main and key element in the calculation of compensation for NPds is the seriousness of the violation. According to the literature, the seriousness of the violation depends on its intensity, on the (especially) serious consequences of the violation and on its duration [11, p. 18]. The intensity of the breach is related to the importance of the breached protected legitimate interest. Not all legal interests protected by the Convention are of equal importance. For example, a violation of a protected legal interest in "procedural justice" is, at least prima facie, less intense than a violation of a protected legal interest of "life, physical and mental integrity" [11, p. 18]. Differences in the level of intensity can be explained by the implicit hierarchy of Convention rights, that is, the ordering of rights according to their relative importance. The Convention itself does not explicitly establish such a hierarchy. However, the order of rights in the Convention, beginning with the right to life (Article 2) and the prohibition of torture (Article 3), can prove their importance. In fact, the Court itself referred to both Art. 2 and Art. 3 as "the most fundamental provisions of the Convention and as" the consolidation of one of the core values of the democratic societies that make up the Council of Europe. Any violation of these rights is likely to be regarded as "serious". Of course, the limits of this argument should be noted: It can hardly be argued that the prohibition of discrimination (Art. 14), although mentioned last in the section on rights and freedoms, is the least important of the Convention's rights. In addition, the fact that some rights have been violated even during emergencies in the country (Article 15) or allow no exceptions such as the prohibition of torture (Article 3) and the prohibition of slavery or servitude. (Art.4 (1)) indicates that the authors of the Convention considered them particularly important [12].

Second, the Court takes the "position of the applicant" into account when calculating the amount of just satisfaction for NPd. What does the Court mean by this? In its jurisprudence, it has e.g., relied on the following applicant-related factors: the age of the applicant, and the applicant's "important judicial status" (as an acting or retired judge). Furthermore, the Court takes "contributory negligence" by the applicant into account and may reduce the amount of NPd. Additionally, the moral conduct of the applicant matters. From a doctrinal point of view, it has been suggested that the moral conduct of the applicant should be taken into account by the Court for calculating the amount, but that it should not play a role when assessing whether or not the applicant is entitled to just satisfaction in the first place. The latter determination

1 Practice Directions (supra note 8), para. 9 ("The Court has ..., until now, considered it inappropriate to accept claims for damages with labels such as 'punitive', 'aggravated' or 'exemplary"'). 
should follow "objective" criteria (such as the seriousness of the violation), unrelated to the applicant's conduct [11, p. 19].

Finally, the amount awarded in respect of NPd depends, according to the statements of the Court, on "the overall context in which the breach occurred", i.e., the "local economic circumstances". The local economic circumstances can be captured by the respondent state. Respondent states have different price levels, which the award in respect of NPd accounts for [11, p. 20].

The main principle, which the ECHR has consistently affirmed in its decisions, is that any interference in nonproperty rights must meet the criterion of proportionality; the intervention must adhere to the criteria of a fair balance between the interests of society and the requirements of the protection of fundamental human rights. On this principle, most of the European Court of Justice also addresses a variety of problems related to NPd. Thus, it can be concluded that the application of the rules on compensation for NPd is associated with the use of many valuation concepts, which are outlined by law with a high degree of relativity, and the decisive role in their proper understanding and application is assigned to the court.

The amount of compensation for NPd must depend on the personal characteristics of the victim. The legislation does not specify what exactly the individual characteristics of the victim may affect the amount of money claimed in order to compensate for NPd. In practice, quite often the victim refers to increased emotionality or to the peculiarities of his psyche. Given the theory of law and current practice, among the psychological features can be distinguished such as: the degree of emotionality of the victim, the level of psychological vulnerability of the victim, the level of self-esteem of the victim, individual features of the victim, the level of development of intelligence, etc. Among the physiological characteristics of the victim, affecting the degree of moral suffering of a person, are the degree of physical development, gender, age, pain threshold, i.e. the ability to endure physical pain, etc.

For example, if a person is physically injured, which disfigures his face, then the young woman will experience more in this situation than the man retired.

V. P. Paliyuk points out that in determining the amount of monetary equivalent of moral suffering of a person, it is necessary to consider all the factors that occur in each individual case and affect the formation of the true amount of moral harm caused [13]. Thus, it distinguishes between general and private criteria.

The general criteria that apply to all categories of cases and without which it is impossible to establish the degree of moral harm and its size, according to the approach of V.P. Paliuk, include:

1. The essence of the claim (one of the main indicators, since only the victim, like no other, can estimate the amount of moral, physical suffering, depth of experience, loss of non-material nature). On this basis, the victim indicates the amount to be recovered, but it is conditional, the final amount is determined by the court.

2. The nature of the act of the person causing the harm and the degree of the defendant's guilt is the attitude of the person causing the harm to their unlawful acts and their consequences. A person should be aware of both the unlawful nature of their behavior and the possibility of harmful consequences. At the same time, VP Paliyuk emphasizes that the fault in civil law serves only as a basis for damages, but neither the form of the fault nor its gravity (degree), as a general rule, affect the amount of responsibility and qualification of the offense.

3. Depth of moral and physical suffering: slight mental or physical pain; significantly; severe and devastating pain for both the mental and physical state of the victim.

4. The nature and degree of moral and physical suffering (mild, moderate, severe).

5. Duration of non-property loss (short-term, longterm, life).

6. Significance of losses (recoverable or irreparable) [15, p. 146].

In conclusion, let us consider the question of another circumstance, which at first glance may seem always worthy of consideration in determining the amount of non-pecuniary damage, the property situation of the victim. As already noted, this circumstance should be taken into account when assessing the nature and extent of suffering suffered by the victim, in a special case - in violation of his property rights. And how is the case in other cases? In principle, in terms of the compensatory function of NPd, i. its purpose for the maximum smoothing of the suffering suffered by the victim, the financial position of the victim, undoubtedly, is very serious.

For example, suppose two victims suffer the same suffering associated with the same violation of personal nonproperty rights (for example, each is slightly harmed by health). However, the annual income of one of the victims exceeds the annual income of the other by 10 thousand times (quite likely the situation with the current ratio of income levels of different sections of the population).

When using the method, we propose, the amount of compensation for alleged NPd will be 24000 EUR. If the annual income of one of the victims is $72000 \mathrm{EUR}$, and the other, respectively, 720000 EUR. The compensation, to the first victim, will obviously bring substantial positive emotions in connection with a significant improvement in his financial position (his annual income will thus increase by more than 30\%), and for the second the amount of compensation in terms of increasing his financial capacity will be simply imperceptible and will not cause any significant positive emotions.

Of course, in this case, too, the victim may have positive emotions in connection with the sense of satisfaction from the very fact of the assignment of property liability to the offender, which corresponds to the penalty function of compensation for moral harm. But it is nevertheless obvious that, depending on the property situation of the victim, a situation is possible when, in the payment of compensation, moral harm will remain virtually uncompensated. Does this mean that the financial position of the victim should be taken into account when determining the amount of compensation, increasing the amount of compensation according to the level of the victim's wellbeing? It seems that this question should be answered in the negative form.

In view of the above, let us try to detail the system of criteria for the amount of liability for moral harm built on the above conceptual bases.

First, in the most generalized form, the criteria for the amount of compensation for moral harm should be under- 
stood as the totality of legal and moral prescriptions, characteristics of certain persons, their legal status and behavior, the circumstances of the case and other phenomena of objective reality which, or substantially, reflect the degree of violation the actions of the imperatives of justice, reasonableness and integrity, or exhibit the ability to determine the extent of compensation and property protection of the victim, necessary and sufficient to restore conviction those parties to the broken legal relationship, as well as all other subjects of civil law in the key role of the mentioned moral and legal principles in the organization of life of society.

Secondly, among the criteria for the amount of proper compensation for the moral harm caused to him, it is advisable to identify groups of factors characterizing the degree of violation of the basic moral values of society, the object of unlawful encroachment, the behavior of the offender, as a cause of moral harm, and behavior contributed to the occurrence of the damage or the increase of its size, forms of realization of the personal non-pecuniary losses caused by the victim (the result of the offense), and in addition, objects independent of the behavior of the parties any circumstances that affected the individual manifestation and the amount of damage inflicted moral or other reasons should be considered immediately for reasons of fairness.

Third, the duration of the violation of the victim's personal non-property rights and interests (the time before the termination of the offense, the consequences of which are of a lasting or prolonged nature - usually in the case of NPd as a result of violation of the public-legal rights of the person), should be considered as a significant factor the condition of the injured person and necessitates an increase in the amount of liability for the NPd caused to him. At the same time, a temporal factor cannot usually be considered as a criterion for reducing the amount of non-pecuniary damage, since compensation is awarded for the suffering experienced over a certain period of time, rather than only those that take place (continue, subsequently arise) at the time of the court case.

Fourth, fairness is both a crucial and integral criterion for determining the proper amount of compensation for non-pecuniary loss sustained by the victim. This feature, among other things, itself provides for a full consideration of considerations of reasonableness and integrity.

Fifth, the legislator and the court practice should take into account the natural differences between individuals and legal entities. Accordingly, the special criteria for determining the amount of compensation for NPd caused to a legal entity should be considered: the sphere of activity and the public-legal status of the offender; the duration of the forced state of uncertainty regarding the continuation of the manifestation of the negative (not only property, but also property) consequences of the committed offense; the nature of the impact of the offense committed on: the stability of the further activity of the injured legal entity; the physical and mental state of the individuals who make up the human substrate of the respective organization (first of all, those who are members of the will of the victim legal entity in civil legal relations or on which the successful functioning of this organization significantly depends). In the context of finding ways to address the fair magnitude of non-pecuniary damage, some scholars and practitioners demonstrate a desire to assert a clearly psychological interpretation of the non-pecuniary loss of a person, and to increasingly involve psychology professionals to provide expert judgment and explanations of various aspects of the moral. and its compensation.

Conclusions and recommendations. There is no stability in awarding mechanisms of non-pecuniary damages by ECHR. Circumstances and grounds that directly affect the determination of the amount of non-pecuniary damage are not clearly defined which leads to the unfair compensation to victim.

The essential point for determining the amount of NPd is the establishment of criteria by which it is possible to find the desired amount of the harm caused, but the legislator does not establish any rules for applying the criteria for determining the amount of non-pecuniary damage and submits the matter to the discretion of the court.

The amount of damage awarded is usually unpredictable and there are no fixed criteria of calculating the right amount of it in each case. In assessing the specific "psychological" consequences of human rights violations, ECHR judges are generally guided not by psychological techniques but by common sense, a reasonable prediction of causing some kind of non-pecuniary harm by certain illegal acts.

There is a need to create a general criterion in setting the fair amount of non-pecuniary damages and calculating the amount of compensation for moral harm, a set of legal and moral prescriptions should be adopted. They should take in the consideration the characteristics of persons, their legal status and behavior, the circumstances of the case and other phenomena of objective reality, which, or substantially reflect the degree of violation of the committed acts, the level of perception of the victim, it directly influences the amount of moral suffering which victim feels; the level of development of intelligence, because in some cases party doesn't even understand that something has happened and, therefore, feels nothing; the level of the intelligence development, as in some cases party doesn't even understand that something has happened and, therefore, feels nothing; the ability of an individual to endure physical pain; the level of psychological vulnerability of the victim .

The criteria for determining the amount of compensation for NPd can be attributed only to such factual circumstances of the violation of the subjective right of the individual, which are capable of significantly affecting the foreseeable manifestation of non-pecuniary damage caused by the victim and the degree of damage to the principles of justice, reasonableness and integrity as a special legal object protection.

\section{REFERENCES}

1. The Recovery of Non-Pecuniary Loss in European Contract Law (2015). In V. Palmer (Ed.) (The Common Core of European Private Law, pp. 21-92). Cambridge: Cambridge University Press.

2. European Convention on Human Rights. Accessed 12 March

2020. https://www.coe.int/en/web/execution/article-41.

3. European Court of Human Rights, Practice Directions: Just Satisfaction Claims (July 1, 2014). Accessed 13 March 2020. http://www.echr.coe.int/Documents/PD_satisfaction_claims_ ENG.pdf, e.g. paras 2, 13, 24. 
4. Burns H. Weston, 20 March 2014, Encyclopedia Britannica, human rights, https://www.britannica.com/topic/human-rights (retrieved 23 February 2020)

5. Atrashkevich V. N. Moral harm - what is it? Young scientist. No. 7. 2016. 187 p.

6. Koziol H. Basic questions of Tort law from a Germanic perspective. Wien: Jan Sramek Verlag, 2012;

7. "Varnava and others v. Turkey", Accessed 06 April 2020 https://hudoc.echr.coe.int/rus\#\{"fulltext":["Varnava\%20and\% 20others\%20v.\%20Turkey"],"documentcollectionid2":["GRA NDCHAMBER","CHAMBER"],"itemid":["001-183638"]\},

8. Practice Directions (supra note 8), paras. 1 and 4. Accessed 08 April

2020.

https://books.google.com.ua/books?id=clFuDwAAQBAJ\&pg $=$ PA107\&lpg=PA107\&dq=Practice+Directions $+($ supra + note $+8),+$ paras $+1+$ and +4 . \& source $=$ bl\&ots $=$ amx-

5QdTDR\&sig=ACfU3U3qLQEtxmZp_PKiISn4gvCMFtIVN A\&hl=ru\&sa $=X \& v e d=2$ ahUKEwi_1p7Ww-

3oAhXCwqYKHdclCGAQ6AEwAHoECAkQLg\#v=onepage $\& q=$ Practice $\% 20$ Directions $\% 20$ (supra\%20note $\% 208) \% 2 \mathrm{C} \%$ 20paras. $\% 201 \% 20$ and $\% 204 . \& \mathrm{f}=$ false.

9. "Konstantin Markin v. Russia", App. Accessed 07 April 2020 https://hudoc.echr.coe.int/rus\#\{ "fulltext":["Konstantin\%20M ar-
kin\%20v.\%20Russia"],"documentcollectionid2":["GRANDC HAMBER","CHAMBER"],"itemid":["001-109868"]\}.

10. "Al-Jedda v. UK”, Accessed 10 April 2020. https://hudoc.echr.coe.int/rus\#\{ "fulltext":["Al-

Jed-

da\%20v.\%20UK"],"documentcollectionid2":["GRANDCHA MBER","CHAMBER"],"itemid":["001-105612"]\}.

11. Altwicker-Hamori, S. and Altwicker, T.and Peters, A., Measuring Violations of Human Rights: An Empirical Analysis of Awards in Respect of Non-Pecuniary Damage Under the ECtHR (July 16, 2015). HJIL, 76 (2016), 1-51. Available at https://ssrn.com/abstract $=2631404$

12. "Mocanu and others v. Romania", App. Accessed 12 April 2020.

https://hudoc.echr.coe.int/rus\#\{ "fulltext":["Mocanu\%20and\% 20others\%20v.\%20Romania"],"documentcollectionid2":["GR ANDCHAMBER","CHAMBER"],"itemid":["001-176239"]\}. 13. Paliyuk V.P. Reparation of moral (non-pecuniary) harm (K.: Law, 2000.) $-272 \mathrm{p}$.

14. Yurenko A.V. Compensation for non-pecuniary damage in foreign countries. (Kharkov 2006), $57 \mathrm{p}$.

15. Paliuk V.P. International judicial institutions and protection of human rights and fundamental freedoms. (Nikolaev: Atoll, 2006). 